\title{
KAPASITAS ANTIOKSIDAN DAN INHIBITOR ALFA GLUKOSIDASE EKSTRAK UMBI BAWANG DAYAK
}

\author{
[Antioxidant and Alpha-Glucosidase Inhibitory Properties of Bawang Dayak Bulb Extracts] \\ Andi Early Febrinda ${ }^{1}{ }^{*}$, Made Astawan ${ }^{2)}$, Tutik Wresdiyati ${ }^{3)}$ dan Nancy Dewi Yuliana ${ }^{2)}$ \\ 1) Program Studi IImu Pangan, Sekolah Pasca Sarjana, Institut Pertanian Bogor, Bogor \\ 2) Departemen IImu dan Teknologi Pangan, Fakultas Teknologi Pertanian, Institut Pertanian Bogor, Bogor \\ 3) Departemen Anatomi, Fisiologi dan Farmakologi, Fakultas Kedokteran Hewan, Institut Pertanian Bogor, Bogor
}

Diterima 07 Februari 2013 / Disetujui 25 November 2013

\begin{abstract}
Bawang dayak (Eleutherine palmifolia) is an indigenous plant in Borneo traditionally used by Dayak tribes to treat any kind of degenerative deseases including diabetes mellitus. The purpose of this research was to measure antioxidant and antidiabetic capacities of water and ethanolic extracts of bawang dayak bulb. Parameters evaluated in this research were phytochemical screening, total phenolics, flavonoid content, DPPH free-radical scavenging activity, and alpha glucosidase inhibiting (AGI) activity. The result showed that the total phenolics and flavonoid content in bawang dayak ethanolic extract (217.71 mg GAE/g and $65.35 \mathrm{mg} \mathrm{QE} / \mathrm{g}$ ) were higher than that of the water extract (139.93 mg GAE/g and 16.95 $m g$ QE/g). The ethanolic extract also had higher antioxidant and AGI activities (IC $C_{50} 112$ and 241 ppm) than that of the water extract (IC $C_{50} 526$ and $505 \mathrm{ppm})$. In addition, the $I_{50}$ values for $A G I$ in bawang dayak ethanolic extract was lower than acarbose which is known as a commercial antidiabetic agent.
\end{abstract}

Keywords: alpha-glucosidase, antioxidant, Eleutherine palmifolia, fenol, flavonoid

\begin{abstract}
ABSTRAK
Umbi bawang dayak (Eleutherine palmifolia) adalah tumbuhan yang banyak dijumpai di Kalimantan Timur dan oleh masyarakat Dayak telah sejak dahulu dimanfaatkan untuk mengobati berbagai macam penyakit diantaranya diabetes melitus. Penelitian ini bertujuan untuk mengukur kapasitas antioksidan dan antidiabetik yang terdapat pada fraksi air dan etanol umbi bawang dayak dengan cara melakukan penapisan fitokimia, pengukuran kandungan fenol dan flavonoid, pengukuran aktivitas penangkal radikal bebas DPPH, dan pengukuran aktivitas inhibitor enzim alfa glukosidase. Hasil penelitian memperlihatkan bahwa total fenol dan total flavonoid yang terkandung di dalam ekstrak etanol (217.71 mg GAE/g dan $65.35 \mathrm{mg} \mathrm{QE} / \mathrm{g}$ ) lebih tinggi dibandingkan dengan ekstrak air (139.93 mg GAE/g dan $16.95 \mathrm{mg} \mathrm{QE} / \mathrm{g}$ ). Seiring dengan hal tersebut aktivitas antioksidan dan inhibitor alfa glukosidase juga lebih tinggi pada ekstrak etanol (nilai IC $5_{50} 112$ dan 241 ppm) dibandingkan dengan ekstrak air (nilai $\mathrm{IC}_{50} 526$ dan $505 \mathrm{ppm}$ ) bahkan nilai $\mathrm{IC}_{50}$ inhibitor alfa glukosidase ekstrak etanol lebih rendah daripada acarbose yang dikenal sebagai agen antidiabetik komersial.
\end{abstract}

Kata kunci: alfa glukosidase, antioksidan, Eleutherine palmifolia, fenol, flavonoid

\section{PENDAHULUAN}

Indonesia memiliki kekayaan hayati yang sangat besar. Berbagai jenis tumbuhan di negeri ini telah menjadi sumber potensial untuk agen terapeutik selama bertahun-tahun dan telah banyak yang berkembang menjadi obat-obatan modern. Kebanyakan senyawa fitokimia seperti fenolik, flavonoid, turunan coumarin dan lainnya yang terkandung di dalam bahan tanaman tertentu diketahui dapat menangkal stres oksidatif di tubuh manusia dengan cara membantu mempertahankan keseimbangan antara oksidan dan antioksidan.

Stres oksidatif adalah suatu keadaan ketika kandungan oksidan atau radikal bebas di dalam tubuh lebih banyak dibandingkan antioksidan. Tubuh memiliki enzim antioksidan

*Penulis Korespondensi:

E-mail: aefebrinda@yahoo.com. Telp. : +6281213559414 alami yang bekerja mengatasi radikal bebas. Namun bila jumlah radikal bebas yang terbentuk sangat banyak sehingga melampaui kemampuan enzim antioksidan untuk mengatasinya maka terjadilah ketidakseimbangan yang disebut stres oksidatif. Selain menyerang protein, stres oksidatif juga terjadi pada bagian membran sel. Proses oksidasi asam lemak tak jenuh yang terdapat pada membran biologis mengakibatkan penurunan fluiditas membran serta rusaknya struktur dan fungsi membran (Tandon et al. 2004). Kerusakan seluler yang ditimbulkan oleh peroksidasi lipid diketahui berhubungan dengan progresi dari berbagai penyakit degeneratif, seperti jantung koroner (Stocker dan Keaney, 2004), diabetes, katarak (Shichi, 2004), penuaan (Ben-Porath dan Weinberg, 2005), dan kanker (Wijeratne et al. 2005). Lee et al. (2004) menjelaskan bahwa antioksidan mampu mencegah kereaktifan radikal bebas melalui tiga mekanisme yaitu pendonoran hidrogen, pengelatan logam, dan quencher oksigen singlet. 
Inhibitor alfa glukosidase (alpha glucosidase inhibitor, AGI) merupakan salah satu agen antidiabetik yang bekerja dengan cara menghambat kerja enzim alfa glukosidase. Pengurangan penyerapan karbohidrat dari makanan oleh usus merupakan sebuah pendekatan terapeutik bagi hiperglikemia postpandrial. Polisakarida kompleks akan dihidrolisis oleh enzim amilase menjadi dekstrin dan dihidrolisis lebih lenjut menjadi glukosa oleh enzim alpha glukosidase sebelum memasuki sirlulasi darah melalui penyerapan epitelium. Amilase dan alpha glukosidase inhibitor sintetis, seperti misalnya acarbose, telah banyak digunakan untuk penanganan pasien diabetes tipe II namun obat ini juga dilaporkan menyebabkan berbagai efek samping (Feng et al. 2011). Sehubungan dengan hal tersebut banyak usaha yang telah dilakukan untuk menemukan $A G I$ dari sumber alami untuk mengobati diabetes. Menurut Shibano et al. (2008) kombinasi $\mathrm{AGl}$ dan antioksidan akan lebih efektif dalam prophylaxis diabetes tipe 2 .

Bawang dayak (Eleutherine palmifolia) merupakan tanaman khas Kalimantan. Tanaman ini memiliki daun berwarna hijau dengan bunga berwarna putih serta umbi berwarna merah yang menyerupai bentuk umbi bawang merah. Air rebusan atau perasan umbi bawang dayak secara tradisional diyakini mempunyai berbagai khasiat, antara lain sebagai obat kanker payudara, darah tinggi (hipertensi), kencing manis (diabetes melitus), kolesterol, dan bisul (Galingging, 2007). Potensi bawang dayak sebagai tanaman obat sangat besar namun kajian ilmiah mengenai khasiat umbi bawang dayak masih sangat sedikit. Penelitian ini dilakukan untuk mempelajari aktivitas antioksidan dan antidiabetik ekstrak air dan ekstrak etanol umbi bawang dayak secara in vitro.

\section{BAHAN DAN METODE}

\section{Bahan}

Umbi bawang dayak (Eleutherine palmifolia) diperoleh dari daerah Samarinda, Kalimantan Timur. Enzim alfa glukosidase (dari Saccharomyces cerevisiae tipe 1), 4-nitrophenyl a-Dglucopyranoside (PNPG), 1.1-diphenyl-2-picrylhydrazyl (DPPH), L-ascorbic acid, Folin-Ciocalteu reagent, asam galat, trolox, $\mathrm{BHT}$ dan quercetain diperoleh dari Sigma-Aldrich.

\section{Persiapan ekstrak}

Ekstraksi umbi bawang dayak dilakukan secara maserasi menggunakan pelarut air dan etanol. Umbi bawang dayak segar dihancurkan menggunakan blender Philips dengan menambahkan pelarut dengan perbandingan 1:4 (b:v). Kemudian larutan direndam selama tiga puluh menit di dalam sonikator GFL 1092. Setelah itu larutan dikocok menggunakan shaker incubator Hitachi L-200 pada suhu ruang selama dua jam. Setelah itu larutan disentrifus menggunakan sentrifus Eppendorf $5810 \mathrm{R}$ dan fase terlarut dikumpulkan untuk disaring menggunakan kertas saring Whatman no 1. Larutan ekstrak yang diperoleh selanjutnya dikeringkan menggunakan pengering beku (Labconco Lyph.Lock 18). Ekstrak kering yang diperoleh dihitung rendemennya menggunakan persamaan di bawah ini.

\footnotetext{
$\%$ Rendemen $=($ gram ekstrak/gram umbi bawang dayak $) \times 100$
}

\section{Penapisan fitokimia (Depkes RI, 1995)}

Penapisan fitokimia yang meliputi analisis kualitatif tanin, alkaloid, flavonoid, saponin, dan triterpenoid dilakukan menurut metode standar yang terdapat di dalam Materia Medika Indonesia (Depkes RI, 1995).

\section{Penentuan kandungan total fenolik (Sahreen et al. 2010)}

Ekstrak air dan ekstrak etanol umbi bawang dayak masingmasing dilarutkan dalam pelarut air dan pelarut etanol (1000 ppm). Sebanyak $1 \mathrm{~mL}$ larutan sampel dicampur dengan $4 \mathrm{~mL}$ larutan natrium karbonat $(75 \mathrm{~g} / \mathrm{L})$ dalam labu takar $10 \mathrm{~mL}$ kemudian dikocok. Pereaksi Folin-Ciocalteu sebanyak $2 \mathrm{~mL}$ dimasukkan ke dalam labu takar tersebut dan dikocok lagi. Setelah homogen ke dalam campuran reaksi ditambahkan aquades hingga tanda tera. Campuran didiamkan di ruang gelap pada suhu kamar selama satu jam. Kemudian diukur absorbansinya pada panjang gelombang $760 \mathrm{~nm}$ menggunakan spektrofotometer Shimadzu UV-160. Sebagai standar digunakan larutan asam galat. Total fenol yang diperoleh dinyatakan sebagai ekivalen asam galat (GAE) dalam mg per gram ekstrak kering.

\section{Penentuan Total Flavonoid Content (TFC) (Mayur et al. 2010)}

Dalam metode ini $10 \mu \mathrm{L}$ ekstrak, $60 \mu \mathrm{L}$ metanol, $10 \mu \mathrm{L}$ aluminium chloride $(10 \% \mathrm{w} / \mathrm{v}), 10 \mu \mathrm{L}$ potassium acetate $(1 \mathrm{M})$ dan $120 \mu \mathrm{L}$ air distilata dicampur merata dan diinkubasi pada suhu ruang selama 30 menit diikuti dengan pengukuran absorbansi pada $415 \mathrm{~nm}$ menggunakan spektrofotometer Shimadzu UV-160. TFC diekspresikan sebagai ekivalen quercetin (QE) dalam mg per gram ekstrak kering.

\section{Analisis kapasitas antioksidan metode DPPH}

Pengujian kapasitas penangkal radikal bebas DPPH dilakukan menurut metode Awah (2010). Sebanyak $2.0 \mathrm{~mL}$ larutan ekstrak pada beberapa konsentrasi yang diencerkan dua kali $(2.5-40 \mu \mathrm{g} / \mathrm{mL})$ dalam etanol dicampurkan dengan 1.0 $\mathrm{mL}$ DPPH $0.5 \mathrm{mM}$ dalam etanol. Campuran tersebut kemudian dikocok dengan kuat dan dibiarkan pada suhu $25^{\circ} \mathrm{C}$ dalam gelap selama 25 menit. Larutan blanko dibuat untuk setiap larutan sampel dengan mencampurkan $2 \mathrm{~mL}$ larutan sampel dan $1.0 \mathrm{~mL}$ etanol. Sebagai kontrol negatif adalah $1.0 \mathrm{~mL}$ larutan DPPH $0.5 \mathrm{mM}$ ditambahkan $2.0 \mathrm{~mL}$ etanol. Absorbansi (Abs) diukur pada panjang gelombang $518 \mathrm{~nm}$ menggunakan spektrofotometer Shimadzu UV-160.

$$
\% \text { inhibisi }=[1-(\text { Abs sampel/Abs kontrol) }] \times 100
$$

Nilai $\mathrm{IC}_{50}$ ditentukan dengan cara membuat kurva antara persen penghambatan versus konsentrasi hingga didapatkan persamaan regresinya. Dari persamaan regresi tersebut dapat ditentukan besaran konsentrasi ekstrak yang memiliki kemampuan penghambatan terhadap aktivitas radikal bebas DPPH sebesar $50 \%$. 
Pengujian aktivitas inhibitor a-glukosidase (Mayur et al. 2010)

Campuran pereaksi yang digunakan dalam uji ini mengandung $50 \mu \mathrm{L}$ fosfat buffer $0.1 \mathrm{M}$ (pH 7.0), $25 \mu \mathrm{L}$ 4nitrophenyl a-D-glukopyranoside $0.5 \mathrm{mM}, 10 \mu \mathrm{L}$ sampel uji pada berbagai konsentrasi (50-1000 ppm) dan $25 \mu \mathrm{L}$ larutan aglukosidase $(0.2 \mathrm{unit} / \mathrm{mL})$. Campuran reaksi ini diinkubasi pada $37^{\circ} \mathrm{C}$ selama 30 menit. Reaksi dihentikan dengan menambahkan $100 \mu \mathrm{L}$ larutan sodium carbonate $0.2 \mathrm{M}$. Hidrolisis enzimatik substrat dimonitor oleh jumlah $p$-nitrophenol yang dilepaskan di dalam campuran reaksi pada $410 \mathrm{~nm}$ menggunakan spektrofotometer Shimadzu UV-160. Blanko individu dipersiapkan untuk mengoreksi absorbansi background dimana enzim digantikan dengan buffer. Kontrol menggunakan pelarut (air atau etanol) menggantikan sampel. Acarbose digunakan sebagai kontrol positif. Seluruh eksperimen dilakukan dalam triplo. Persentase inhibisi dari a-glukosidase didapatkan dengan formula berikut:

\section{$\%$ inhibisi $=[1-($ Abs sampel /Abs kontrol) $] \times 100$}

Nilai $\mathrm{IC}_{50}$ ditentukan dengan cara membuat kurva antara persen penghambatan versus konsentrasi hingga didapatkan persamaan regresinya. Dari persamaan regresi tersebut dapat ditentukan besaran konsentrasi ekstrak yang memiliki kemampuan penghambatan terhadap aktivitas enzim alpha glukosidase sebesar $50 \%$.

\section{Analisis statistik}

Semua analisis dilakukan secara triplo. Semua hasil ditampilkan sebagai rataan \pm SD. Analisis data dilakukan menggunakan analisa deskriptif dan analisa perbandingan nilai rataan. Analisa perbandingan nilai rataan dilakukan menggunakan one sample t-test.

\section{HASIL DAN PEMBAHASAN}

\section{Rendemen}

Ekstraksi umbi bawang dayak dengan pelarut air memberikan rendemen sebesar $7.57 \pm 1.18 \%$ sedangkan untuk pelarut etanol memberikan rendemen sebesar $6.67 \pm 0.39 \%$. Berdasarkan uji statistik one-sample t-test terdapat perbedaan yang signifikan dari kedua jenis pelarut dimana ekstraksi menggunakan pelarut air memberikan rendemen ekstrak yang lebih besar dibandingkan dengan pelarut etanol.

\section{Penapisan fitokimia}

Hasil analisis fitokimia terhadap ekstrak air dan etanol umbi bawang dayak disajikan pada Tabel 1. Jenis senyawa fitokimia yang menonjol pada ekstrak etanol (alkaloid, tanin, fenolik, flavonoid, dan triterpenoid) lebih banyak dibandingkan yang ditemukan pada ekstrak air (alkaloid, fenolik, dan triterpenoid). Semua jenis senyawa tersebut diketahui memiliki aktivitas antioksidan.
Tabel 1. Hasil penapisan fitokimia ekstrak air dan etanol umbi bawang dayak

\begin{tabular}{|c|c|c|}
\hline \multirow{2}{*}{ Jenis Pengujian } & \multicolumn{2}{|c|}{ Jenis Ekstrak } \\
\hline & Air & Etanol \\
\hline Alkaloid & +++ & ++ \\
\hline Saponin & + & + \\
\hline Tanin & + & ++ \\
\hline Fenolik & ++ & +++ \\
\hline Flavonoid & - & +++ \\
\hline Triterpenoid & ++++ & ++++ \\
\hline Steroid & + & + \\
\hline
\end{tabular}

\section{Total fenol dan total flavonoid}

Hasil penelitian menunjukkan bahwa ekstrak etanol umbi bawang dayak mengandung senyawa fenolik dan flavonoid

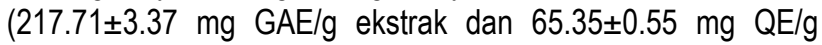
ekstrak) dalam jumlah yang lebih besar dibandingkan ekstrak air (139.93 $\pm 4.44 \mathrm{mg} \mathrm{GAE} / \mathrm{g}$ ekstrak dan $16.95 \pm 0.55 \mathrm{mg} \mathrm{QE} / \mathrm{g}$ ekstrak), sebagaimana terlihat pada Gambar 1.

Komponen polifenol pada tanaman diketahui memiliki sifat multifungsi seperti pereduksi, menyumbangkan atom hidrogen sebagai antioksidan dan peredam terbentuknya singlet oksigen. Flavonoid dan turunannya merupakan golongan polifenol yang banyak dan sangat penting pada tanaman. Sifat yang penting dari golongan polifenol adalah kemampuannya bertindak sebagai antioksidan. Penentuan kandungan total fenolik pada penelitian ini dilakukan dengan menggunakan pereaksi FolinCiocalteau. Metode ini berdasarkan kekuatan mereduksi dari gugus hidroksi fenolik. Semua senyawa fenolik termasuk fenol sederhana dapat bereaksi dengan pereaksi Folin Ciocalteau. Adanya inti aromatis pada senyawa fenol (gugus hidroksi fenolik) dapat mereduksi fosfomolibdat fosfotungstat menjadi molibdenum yang berwarna biru. Menurut Bettuzzi et al. (2006), senyawa dari golongan polifenol memiliki aktivitas antioksidan yang sangat kuat. Aktivitas antioksidan komponen polifenol ditandai dengan aktivitas yang relatif tinggi sebagai donor hidrogen atau elektron dan kemampuan dari turunan radikal polifenol untuk menstabilkan dan memindahkan elektron yang tidak berpasangan (fungsi pemutusan rantai), serta kemampuan untuk mengkelat transisi logam.

Eleutherine palmifolia termasuk ke dalam genus Iridaceae. Spesies dari genus Iris (Iridaceae) telah memiliki sejarah yang panjang dalam pengobatan tradisional di dunia, dan sejak dahulu telah diketahui memiliki banyak kandungan metabolit sekunder terutama flavonoid (Wang et al. 2010 b). Pada penelitian terhadap ekstrak etanol Eleutherine americana yang tumbuh di Thailand, Ifesan et al. (2009) menyebutkan bahwa total phenol dari ekstrak tersebut adalah $4.56 \mu \mathrm{mol}$ asam galat ekivalen/g ekstrak kering dan memiliki kemampuan penghambatan terhadap aktivitas radikal bebas DPPH dengan nilai $\mathrm{IC}_{50}$ sebesar $8.4 \mu \mathrm{g} / \mathrm{mL}$. Hubungan antara kandungan total fenol dan aktivitas antioksidan juga ditunjukkan oleh penelitian yang dilakukan oleh Vrcek et al. (2011) yang memperlihatkan kandungan total fenol di dalam berbagai jenis wine Croatian dan kandungan antioksidannya. Aktivitas antioksidan yang ditentukan dengan metode DPPH dan ABTS dari 10 jenis wine Croatian yang diteliti berkorelasi positif dengan kandungan total fenolnya dengan koefisien korelasi sebesar 0.9926 dan 0.0938 . 


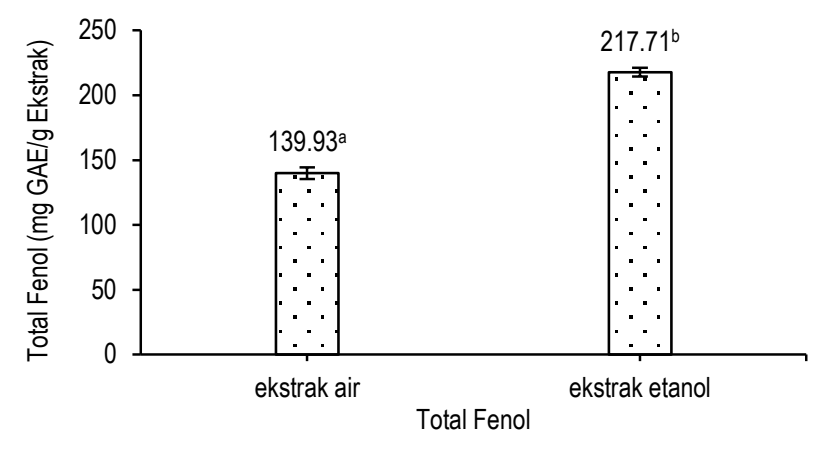

Gambar 1. Nilai total fenol ekstrak air dan ekstrak etanol umbi bawang dayak. Notasi berbeda menunjukkan kedua nilai berbeda signifikan menurut hasil uji beda one sample t-test pada tingkat kepercayaan $95 \%$

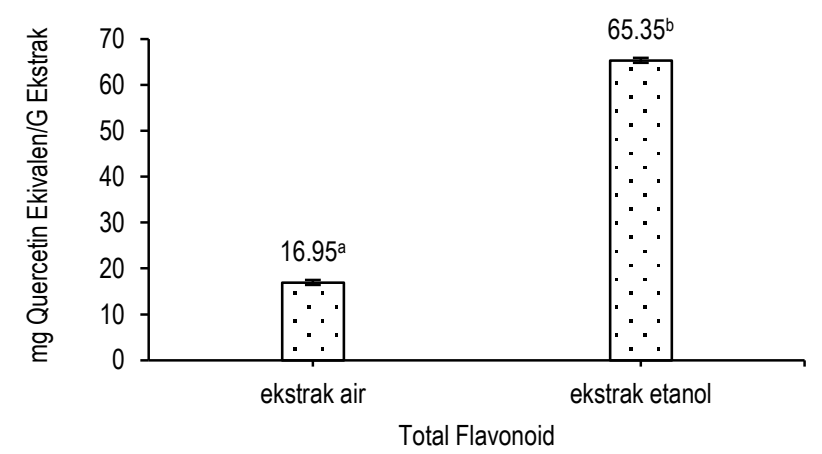

Gambar 2. Nilai total flavonoid ekstrak air dan ekstrak etanol umbi bawang dayak. Notasi berbeda menunjukkan kedua nilai berbeda signifikan menurut hasil uji beda one sample t-test pada tingkat kepercayaan $95 \%$

\section{Aktivitas penangkal radikal bebas DPPH}

Nilai aktivitas penangkal radikal bebas yang diperoleh dalam bentuk penyetaraannya terhadap antioksidan standar (asam askorbat, BHT, dan trolox) disajikan pada Tabel 2 dimana dapat dilihat bahwa aktivitas ekstrak etanol lebih besar dibandingkan dengan aktivitas yang dimiliki oleh ekstrak air.

Tabel 2. Aktivitas antioksidan ekstrak air dan etanol umbi bawang dayak dalam satuan nilai setara antioksidan standar (asam askorbat, BHT dan Trolox)

\begin{tabular}{lcc}
\hline \multicolumn{1}{c}{ Satuan Aktivitas Antioksidan } & Ekstrak Air & Ekstrak Etanol \\
\hline mg Asam askorbat ekivalen / g & $70.88 \pm 12.89$ & $117.98 \pm 9.69$ \\
ekstrak & $114.41 \pm 27.70$ & $215.32 \pm 20.82$ \\
mg BHT ekivalen / g ekstrak & $113.87 \pm 20.04$ & $187.09 \pm 15.06$ \\
mg Trolox ekivalen / g ekstrak & & \\
\hline
\end{tabular}

Menurut IUPAC (2006) IC $\mathrm{C}_{50}$ adalah konsentrasi suatu senyawa yang menyebabkan penghambatan sebesar 50\% terhadap sebuah sistem yang diberikan. Dengan demikian untuk aktivitas penangkal radikal bebas DPPH nilai I $\mathrm{C}_{50}$ dapat diartikan sebagai konsentrasi ekstrak yang menyebabkan penurunan konsentrasi DPPH sebesar $50 \%$ dari konsentrasi DPPH awal. Dari persamaan regresi pada Gambar 3 dan 4 diperoleh nilai $\mathrm{IC}_{50}$ untuk ekstrak etanol dan ekstrak air masing masing adalah 112 dan 526 ppm.

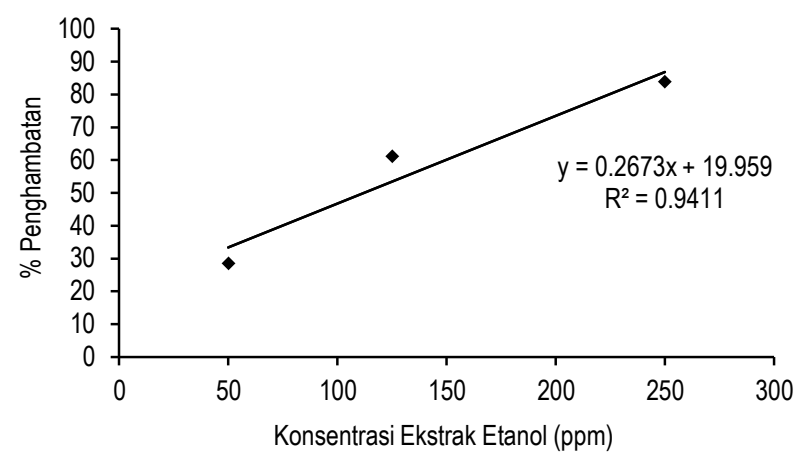

Gambar 3. Persamaan regresi untuk menghitung nilai $I_{50}$ penghambatan aktivitas radikal bebas DPPH oleh ekstrak etanol umbi bawang dayak

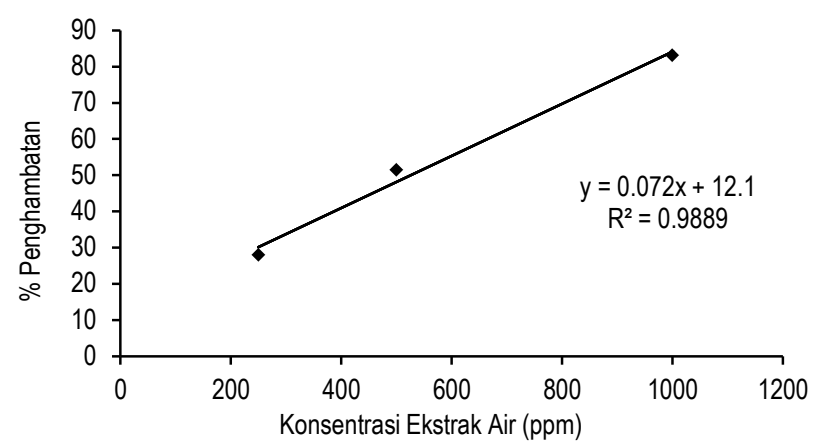

Gambar 4. Persamaan regresi untuk menghitung nilai $\mathrm{IC}_{50}$ penghambatan aktivitas radikal bebas DPPH oleh ekstrak air umbi bawang dayak

Efektivitas flavonoid dalam menangkal radikal DPPH sebagian besar bergantung pada struktur, hidrofobisitas, aktivitas biologis dan juga aktivitas oksidatif. Kemampuan dan pemutusan reaksi berantai radikal oleh flavonoid terutama bergantung pada kehadiran setidaknya dua kelompok ohidroksil pada cincin B. Hal ini memungkinkan pembentukan ikatan hidrogen intramolekul antara kelompok hidroksil yang meningkatkan stabilitas radikal fenoksil (Majewska et al. 2011). Sedangkan menurut Amic et al. (2003) flavonoid akan memiliki aktivitas antiradikal yang tinggi bila memiliki grup 3'.4'-dihidroxypada cincin B dan/atau memiliki grup 3-OH di sebelah 4-keto. Selain senyawa fenol dan polifenol, senyawa triterpenoid juga diketahui memiliki aktivitas antioksidan yang tinggi sebagaimana dikemukakan oleh Grace-Lynn et al. (2012).

Nilai I $\mathrm{C}_{50}$ ekstrak etanol yang lebih kecil daripada ekstrak air menunjukkan bahwa ekstrak etanol memiliki kemampuan yang lebih tinggi dibandingkan dengan ekstrak air dalam menghambat aktivitas radikal bebas DPPH. Hal ini sesuai dengan hasil pengukuran sebelumnya baik secara kualitatif maupun kuantitatif dimana ekstrak etanol umbi bawang dayak memiliki lebih banyak jenis senyawa fitokimia serta memiliki nilai total fenolik dan total flavonoid yang lebih tinggi daripada ekstrak air. Pada kondisi diabetes mellitus terjadi penguatan produksi Radical Oxygen Species sehingga mengakibatkan tubuh mengalami stres oksidatif (Kumar et al. 2010). Stres oksidatif adalah suatu keadaan di mana kandungan oksidan atau radikal bebas dalam tubuh lebih banyak dibandingkan antioksidan 
(Bonnefont-Rousselot et al. 2000). Di sisi lain, defisiensi insulin pada DM menyebabkan berbagai kekacauan dalam proses metabolisme dan regulasi yang pada gilirannya menyebabkan akumulasi lemak seperti kolesterol total. Hal ini bisa terjadi karena kekurangan insulin menyebabkan peningkatan mobilisasi asam lemak bebas dari jaringan adiposa yang menghasilkan peningkatan produksi LDL- kolesterol (Latha dan Daisy, 2011). Oksidasi kolesterol LDL merupakan salah satu alasan utama terjadinya aterosklerosis pada manusia (Wiztum, 1991) dan tingginya kolesterol total dan kolesterol LDL dalam darah merupakan faktor risiko utama penyakit koroner (Tchobroutsky, 1978). Dengan demikian antioksidan berperan sangat penting dalam mencegah terjadinya komplikasi pada pasien DM. Menurut Lee et al. (2004) sistem proteksi non enzimatik terhadap stres oksidatif dapat berupa vitamin $C$, vitamin E, karotenoid, dan polifenol. Karotenoid bersifat antioksidan dengan kemampuannya bertindak sebagai quencher radikal bebas. Polifenol dapat bersifat sebagai antioksidan karena kemampuannya mendonorkan atom hidrogen, scavenger radikal bebas, dan pengelat ion logam.

\section{Penghambatan aktivitas enzim alfa glukosidase}

Dalam penelitian ini kemampuan hipoglikemik potensial umbi bawang dayak diuji secara in vitro melalui pengukuran penghambatan aktivitas enzim alfa glukosidase. Sebagai pembanding digunakan acarbose yang merupakan agen antidiabetik komersial yang bekerja dengan cara menghambat kerja enzim alfa glukosidase. Hasil yang disajikan pada Tabel 3 menunjukkan bahwa baik untuk ekstrak etanol maupun ekstrak air kemampuan penghambatan enzim alfa glukosidase merupakan aktivitas yang bergantung pada konsentrasi.

Dari Tabel 3 dapat dibuat persamaan regresi untuk menentukan nilai $\mathrm{IC}_{50}$ ekstrak air, ekstrak etanol, dan acarbose dalam menghambat aktivitas enzim alfa glukosidase (Gambar 5, 6 dan 7). Nilai IC 50 tersebut disajikan pada Gambar 8.

Tabel 3. Aktivitas inhibitor alfa glukosidase umbi bawang dayak

\begin{tabular}{lcc}
\hline \multicolumn{1}{c}{ Sampel } & Konsentrasi $(\mathrm{ppm})$ & \% Penghambatan \\
\hline Air & 50 & $10.51 \pm 3.33$ \\
& 100 & $15.13 \pm 2.82$ \\
& 250 & $36.15 \pm 7.40$ \\
Etanol & 500 & $46.67 \pm 6.15$ \\
& 50 & $21.52 \pm 1.30$ \\
Acarbose & 100 & $29.33 \pm 2.32$ \\
& 250 & $51.27 \pm 1.48$ \\
& 50 & $13.92 \pm 4.64$ \\
& 100 & $22.15 \pm 3.59$ \\
& 250 & $35.87 \pm 0.84$ \\
\hline
\end{tabular}

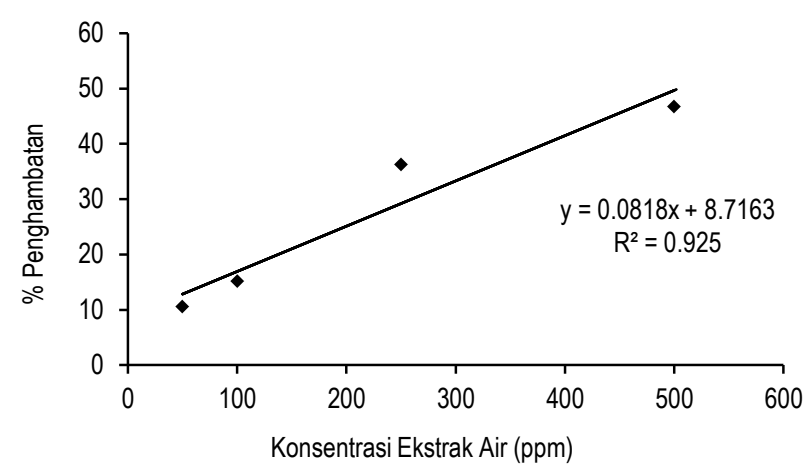

Gambar 5. Persamaan regresi untuk menghitung nilai $\mathrm{IC}_{50}$ penghambatan aktivitas enzim alfa glukosidase oleh ekstrak air umbi bawang dayak

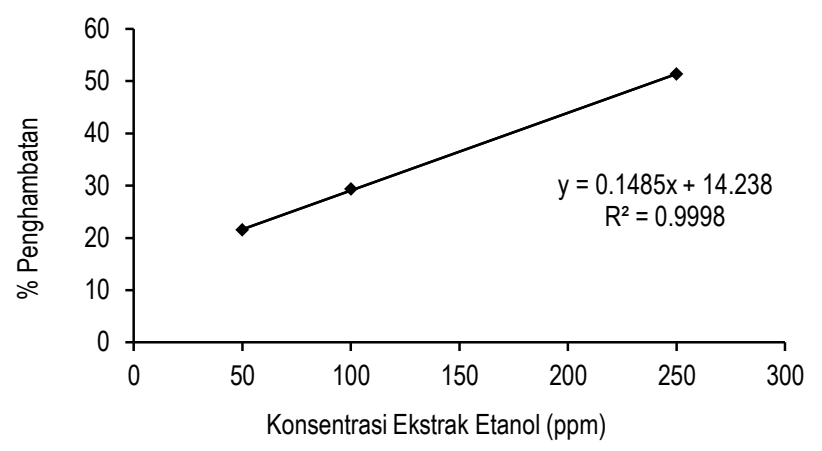

Gambar 6. Persamaan regresi untuk menghitung nilai $\mathrm{I}_{50}$ penghambatan aktivitas enzim alfa glukosidase oleh ekstrak etanol umbi bawang dayak

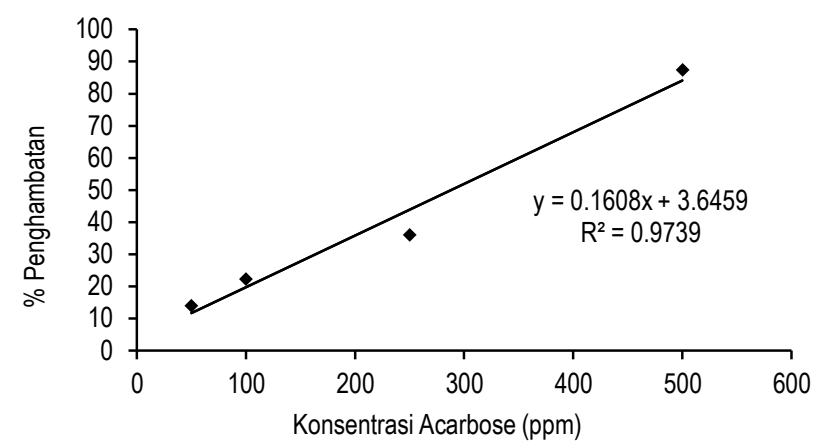

Gambar 7. Persamaan regresi untuk menghitung nilai $\mathrm{IC}_{50}$ penghambatan aktivitas enzim alfa glukosidase oleh senyawa acarbose

Data dari Gambar 8 memperlihatkan bahwa ekstrak etanol memiliki kemampuan signifikan lebih besar dalam menghambat aktivitas enzim alfa glukosidase dibandingkan dengan ekstrak air, dan aktivititas tersebut setara dengan yang dimiliki oleh acarbose. 


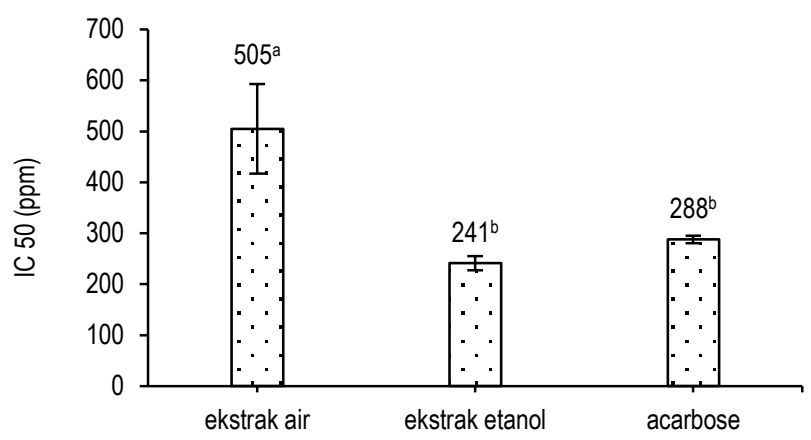

Gambar 8. Nilai $I_{50}$ penghambatan enzim alfa glukosidase. Notas berbeda menunjukkan beda signifikan menurut hasil uji DMRT pada tingkat kepercayaan $95 \%$

Acarbose merupakan senyawa oligosakarida yang berasal dari proses fermentasi mikroorganisme Actinoplanes utahenis, dikenal dengan nama kimia 0-4,6-dideoxy-4-[[(1S,4R,5S,6S)4,5,6-trihydroxy-3-(hydroxymethyl)-2-cyclohexen-1-yl] amino]-a D-glucopyranosyl-(1->4)-O-a-D-glucopyranosyl-(1->4)-Dglucose dan memiliki rumus empiris $\mathrm{C}_{25} \mathrm{H}_{43} \mathrm{NO}_{18}$. Senyawa oligosakarida kompleks ini merupakan inhibitor kompetitif potensial dari enzim alpha glukosidase yang bekerja di brush border untuk memecah pati, dekstrin, maltose, dan sukrosa hingga menghasilkan monosakarida yang dapat dicerna. Berdasarkan sifat tersebut maka acarbose merupakan salah satu agen antidiabetik oral bagi pasien diabetes mellitus tipe 2. Efek samping yang dirasakan kebanyakan pasien yang menggunakan acarbose adalah flatulensi, diare, dan sakit perut (Hollander et al. 1997).

Alfa glukosidase adalah enzim yang mengkatalisis pemotongan ikatan glikosidik pada oligosakarida. Beberapa glukosidase yang bekerja spesifik dalam memotong ikatan glikosidik bergantung pada jumlah, posisi, atau konfigurasi grup hidroksil di dalam molekul gula. Aktivitas glukosidase merupakan hal yang fundamental bagi beberapa proses biokimia seperti degradasi polisakarida menjadi unit mono-sakarida, agar dapat diserap dan digunakan oleh organisme. (de Melo et al. 2006). Oleh karena itu pada kondisi hiperglikemia dimana konsentrasi gula pada darah tinggi melebihi normal seperti yang terjadi pada penderita diabetes, penghambatan kerja enzim alfa glukosidase dapat membantu mengatasi kondisi hiperglikemia karena jumlah monosakarida yang dapat diserap oleh usus menjadi berkurang.

Banyak penelitian telah membuktikan bahwa senyawa fitokimia memiliki kemampuan untuk menghambat kerja enzim alfa glukosidase, seperti senyawa dari golongan alkaloid (Patel et al. 2012), triterpenes (Lai et al. 2012), dan flavonoid (Wang et al. 2010a) Penghambatan aktivitas alfa glukosidase oleh berbagai senyawa fenolik juga telah banyak dijelaskan dalam literatur, dimana antara lain disebutkan bahwa alfa glukosidase secara efektif dihambat oleh flavonol (Lee et al. 2008), luteolin, myricetin, dan quercetin (Tadera et al. 2006). Dengan demikian kemampuan aktivitas inhibitor alfa glukosidase yang dimiliki oleh ekstrak umbi bawang dayak tidak lepas dari kerja senyawa fitokimia yang dikandungnya. Menurut Kim et al. (2008) sebagian besar inhibitor alfa glukosidase bekerja dengan cara meniru cara meniru posisi transisi unit piranosidik dari substrat glukosidase alami, sehingga diduga mekanisme penghambatannya adalah berupa penghambatan kompetitif. Perlu dilakukan isolasi dengan teknik spektrofotometri massa untuk mengungkapkan senyawa bioaktif yang bekerja sebagai inhibitor alfa glukosidase di dalam ekstrak air dan ekstrak etanol umbi bawang dayak agar dapat diketahui mekanisme penghambatannya.

Tingginya aktivitas penghambatan terhadap enzim alfa glukosidase pada ekstrak etanol dibandingkan dengan ekstrak air adalah sejalan dengan hasil yang ditunjukkan secara kualitatif dan kuantitatif pada penapisan fitokimia dan pengukuran total fenolik dan flavonoid, dimana jenis senyawa fitokimia lebih menonjol ditemukan pada ekstrak etanol dibandingkan ekstrak air, serta kandungan total fenolik dan flavonoid lebih tinggi pada ekstrak etanol dibandingkan ekstrak air.

\section{KESIMPULAN}

Aktivitas antioksidan dan inhibitor alfa glukosidase yang terdapat pada ekstrak etanol umbi bawang dayak lebih besar dibandingkan yang terdapat pada ekstrak air. Hasil penapisan fitokimia dan penghitungan total flavonoid dan total fenol juga memperlihatkan jenis dan kandungan senyawa fitokimia yang lebih besar pada ekstrak etanol dibandingkan pada ekstrak air. Perpaduan kapasitas antioksidan dan kemampuan penghambatan enzim alfa glukosidase yang terdapat pada umbi bawang dayak menunjukkan bahwa umbi bawang dayak memiliki potensi sebagai agen antidiabetik yang bermanfaat dalam pencegahan dan perlindungan (prophylaxis) terhadap penyakit diabetes melitus.

\section{UCAPAN TERIMA KASIH}

Penelitian ini sebagian didanai oleh Yayasan Institut Danone Indonesia melalui Doctorate Research Fund Tahun 2012, dan Dirjen Pendidikan Tinggi melalui Penelitian Hibah Bersaing Tahun 2013.

\section{DAFTAR PUSTAKA}

Amic D, Davidovic-Amic D, Beslo D, Trinajstic N. 2003. Structure-radical scavenging activity relationships of flavonoids. Croat Chem Acta 76: 55-61.

Awah FM, Uzoegwu PN, Oyugi JO, Rutherford J, Ifeonu P, Yao XJ, Fowke KR, Eze MO. 2010. Free radical scavenging activity and immunomodulatory effect of Stachytarpheta angustifolia leaf extract. Food Chem 119: 1409-1416. DOI: 10.1016/j.foodchem.2009.09.020.

Ben-Porath I, Weinberg RA. 2005. The signals and pathways activating cellular senescence. Int J Biochem Cell B 37: 961-976. DOI: 10.1016/j.biocel.2004.10.013.

Bettuzzi S, Brausi M, Rizzi F, Castagnetti G, Peracchia G, Corti A. 2006. Chemoprevention of human prostate cancer by oral administration of green tea catechins in volunteers with 
high-grade prostate intraepithelial neoplasia: a preliminary report forom a one-year proof-of-principle study. Cancer Res 66: 1234-1240. DOI: 10.1158/0008-5472.CAN-051145.

[Depkes RI] Departemen Kesehatan Republik Indonesia. 1995. Materia Medika Indonesia. Jilid VI. Departemen Kesehatan RI, Direktorat Jenderal Pengawasan Obat dan Makanan. Jakarta.

Feng J, Yang XW, Wang RF. 2011. Bio-assay guided isolation and identification of a-glucosidase inhibitors from the leaves of Aquilaria sinensis. Phytochemistry 72: 242-247. DOI: 10.1016/j.phytochem.2010.11.025.

Galingging RY. 2007. Potensi plasma nutfah tanaman obat sebagai sumber biofarmaka di Kalimantan Tengah. J Pengkajian dan Pengembangan Teknologi Pertanian 10: 76-83.

Grace-Lynn C, Darah I, Chen Y, Latha LY, Jothy SL, Sasidharan S. 2012. In vitro antioxidant activity potential of lantadene $A$, a pentacyclic triterpenid of lantana plants. Molecules 17: 11185-11198. DOI: 10.3390/molecules 170911185.

Hollander P, Pi-Sunyer X, Conifff RF. 1997. Acarbose in the treatment of type 1 diabetes. Diabetes Care 20: 248-253. DOI: 10.2337/diacare.20.3.248.

Ifesan BOT, Siripongvutikom S, Hutadilok-Towatana N, Voravuthikunchai SP. 2009. Evaluation of the ability of Eleutherine americana crude extract as natural food additive in cooked pork. J Food Sci 74: M352-M357. DOI: 10.1111/ j.1750-3841.2009.01254.x.

Lai YC, Chen CK, Tsai SF, Lee SS. 2012. Triterpenes as aglucosidase inhibitors from Fagus hayatae. Phytochemistry 74: 206-211. DOI: 10.1016/j.phytochem.2011.09.016.

Lee J, Koo N, Min DB. 2004. Reactive oxigen species, aging, and antioxidative nutreceuticals. Compr Rev Food Sci F 3: 21-33. DOI: 10.1111/j.1541-4337.2004.tb00058.x.

Lee SS, Lin HC, Chen CK. 2008. Acylated flavonol monorhamnosides, a-glucosidase inhibitors, from Machilus phillippinensis. Phytochemistry 69: 2347-2353. DOI: 10.1016/j.phytochem.2008.06.006.

Majewska M, Skrzycki M, Podsiad M, Czeczot H. 2011. Evaluation of antioxidant potential of flavonoids: an in vitro study. Acta Pol Pharm 68: 611-615.
Mayur B, Sandesh S, Shruti S, Sung-Yum S. 2010. Antioxidant and a-glucosidase inhibitory properties of Carpesium abrotanoides L. J Med Plants Res 4: 1547-1553. DOI: 10.5897/JMPR10.210.

Patel MB, Mishra SM. 2012. Magnoflorine from Tinospora cordifolia stem inhibits . a-glucosidase and is antiglycemic in rats. J Funct Foods 4: 79-86. DOI: 10.1016/j.jff.2011.08.002.

Sahreen S, Khan MR, Khan RA. 2010. Evaluation of antioxidant activities of various solvent extracts of Carissa opacus fruits. Food Chem 122: 1205-1211. DOI: 10.1016/j.foodchem. 2010.03.120.

Shibano M, Kakutani K, Taniguchi M, Yasuda M, Baba K. 2008. Antioxidant constituents in the dayflower (Commelina communis L.) and their alpha-glucosidase-inhibitory activity. J Nat Med 62: 349-353. DOI: 10.1007/s11418-008-0244-1.

Shichi H. 2004. Cataract formation and prevention. Expert Opin Inv Drug13: 691-701. DOI: 10.1517/13543784.13.6.691.

Stocker R, Keaney JFJr. 2004. Role of oxidative modifications in atherosclerosis. Physiol Rev 84: 1381-1478. DOI: 10. 1152/physrev.00047.2003.

Tadera K, Minami Y, Takamatsu K, Matsuoka T. 2006. Inhibition of a-glucosidase and a-amylase by flavonoids. J Nutr Sci Vitaminol 52: 149-153. DOI: 10.3177/jnsv.52.149.

Tandon R, Khanna HD, Dorababu M, Goel RK. 2004. Oxidative stress and antioxidant status in peptic ulcer and gastric carcinoma. Indian J Physiol Pharmacol 48: 115-118.

Vrcek IV, Bojic M, Zuntar I, Mendas G, Medic-Saric M. 2011. Phenol content, antioxidant activity dan metal composition of croatian wines deriving from organically and conventionally grown grapes. Food Chem 124: 354-361. DOI: 10.1016/j.foodchem.2010.05.118.

Wang H, Du YJ, Song HC. 2010a. a-Glucosidase and aamylase inhibitory activities of guava leaves. Food Chem 123: 6-13. DOI: 10.1016/j.foodchem.2010.03.088.

Wang $\mathrm{H}$, Cui $\mathrm{Y}$, Zhao C. $2010^{\mathrm{b}}$. Flavonoids of the genus Iris (Iridaceae). Mini-Rev Med Chem 10: 643-661. DOI: 10.2174/138955710791384027.

Wijeratne SSK, Cuppett SL, Schlegel V. 2005. Hydrogen peroxide induced oxidative stress damage and antioxidant enzyme response in caco-2 human colon cells. J Agr Food Chem 53: 8768-8774. DOI: 10.1021/jf0512003. 